Article

\title{
Deleuze contra Hegel: The Rupture of the Dialectics towards Non-Conceptual Difference
}

Raniel SM. Reyes

\begin{abstract}
This paper is a brief philosophical analysis of the relationship between G.W.F. Hegel and Gilles Deleuze's philosophy. In the first part, I will present Hegel's dialectical philosophy as the opus' point of departure including a truncated elucidation of the totalitarian aspect of his thinking. Since the Hegelian system is very comprehensive, it has also influenced other parts of Europe, especially France. Upon its arrival in the French soil, the system's structurality was re-attuned in accordance with the materialities engendered by the political events besetting the French society during the 1960s. In order to explicate this hermeneutical fusion of horizons, I will utilize Deleuze's philosophy of difference in order to undermine the Hegelian system. However, as Deleuze's intellectual career progresses, his radicalism has mitigated. From an inclusive diagnosis of the said system, it has merely ruptured the metaphysical walls of the dialectic to become sensible to the pluralistic voices of difference. Amidst this so-called Deleuzian turn, I will delineate in the last part some additional albeit sophisticated convergence between their philosophies.
\end{abstract}

Keywords: Deleuze, Hegel, dialectics, difference

\section{Revisiting the Hegelian Dialectics and the Specter of Totalitarianism}

$\mathrm{P}$ hilosophy is not merely a search for the ultimate truths of reality and a reflection of our lived experiences. It is likewise a radicalization of the present order. Although the German Hegel and the French Deleuze are progenies of different historical periods and intellectual traditions, they have devised their respective critiques against the representationalist metaphysics of their times. However, despite this perceived convergence, there remains a complex divergence between them specifically, their means 
of confronting representation. On one hand, we have a very systematic and rigorous thinker in Hegel, and we have an eccentric and rhizomic philosopher in Deleuze, on the other. Let us start with the philosophy of Hegel.

Hegel's intellectual system is undeniably one of the most towering theoretical eyeglasses of modernity. Other thinkers are only left constructing their projects as a reaction to his philosophy, yet they end up simply being subsumed by the profundity of the system or ending as anti-Hegelian Hegelians. Traditionally, when we talk about Hegel, our starting point is the notion of the dialectic. This principle is a very important concept in understanding his Logic, Philosophy of Nature, and Phenomenology of the Spirit. In these major writings, he characterizes the dialectic as the dialectic of the Logic that ingeniously manifested itself in natural and spiritual phenomena and consciousness. ${ }^{1}$ In Science of Logic, the dialectic is illustrated to be the principle capable of explicating our understanding of basic categories such as concept and judgment. ${ }^{2}$ As each category implicitly contains the force of selfcontradiction, it will be reconciled or sublated in the long run to craft a higher form of unity towards a grand collective synthesis in the Absolute. Meanwhile, the Phenomenology of the Spirit chronicles the experience of consciousness as it traverses the primitive state going to the Absolute. ${ }^{3}$ Two important points can be ruminated from the aforementioned statement. Firstly, the Hegelian philosophy is an overcoming of the Cartesian metaphysics where the $I$ (self) is deemed as given, i.e., detached from all material contingencies. Secondly, the nature of reality, unlike the Kantian epistemological demarcations, can already be accessed thinly through a series of dialectical struggles. Following the words of Hegel:

The logical has in point of form three sides ... These three sides do not constitute three parts of the Logic, but are moments of each logical reality, that is, of each concept ... a) Thought, as the Understanding, sticks to finite determinacies and their distinctness from one another ... b) The dialectical moment is the self-sublation of such finite determinations and their transition into their opposites ... c) The speculative moment, or that of positive Reason, apprehends the unity of the

\footnotetext{
${ }^{1}$ Frederick Beiser, ed., The Cambridge Companion to Hegel (Cambridge: Cambridge University Press, 1993), 131.

2 G.W.F. Hegel, Science of Logic, trans. by A. V. Miller (London: Allen \& Unwin; New York: Humanities Press, 1969).

${ }^{3}$ Stephen Houlgate, The Hegel Reader (MA: Blackwell Publishing, 1998), 56.

(c) 2014 Raniel SM. Reyes

http://www.kritike.org/journal/issue 15/reyes december2014.pdf

ISSN 1908-7330

(cc) BY-NC
} 
determinations in their opposition - the affirmation that is contained in their dissolution and transition. ${ }^{4}$

Under Hegel's re-reading of the modern tradition, Reason (the overarching principle of this epoch) is not anymore reduced to mere Cartesian Cogito. It is rather conceived as a materially-conditioned principle operating within the realm of the human condition. Using this new theoretical lens, reason is situated in the topography of history, i.e., as something that evolves from the primitive, religious, going to the realm of philosophy. As it elevates from one stage into another, the reformulation of (its) freedom is likewise observable from being the voice of a single subjectivity to becoming the voice of intersubjectivities concretized in the different social institutions. For this reason, the solutions to the numerous binaries in modernity that fragmented reality and estranged life can be positioned in the landscape of culture and is possible only via a clearer dialectical perception of reason. In this Hegelian parlance, reason is introduced into a new kind of modernity wherein another brand of liberty from its metaphysically-optimistic delusion is rendered to itself. This novel brand of emancipation is a new philosophy of creativity geared to embattle modernity's foundationalism or representationalism. Further, this attribute is vitally contributory to reason's disposal of its assimilative mentality, the very conceptual aberration responsible for the various problematic dichotomies and violence in modernity. Therefore, a philosophy becoming art-like in Hegel's mind is tantamount to reason learning how to be dialectical, as well as reality being perceived as embedded in the fluid realm of material processes and antagonisms. This remarkable craftsmanship is a form of thinking capable of reconciling all modern dichotomies differentially.

Additionally, Kant's noumenon can already be known (indirectly) in the arena of historical configurations. When things are viewed in the ambit of the immanent field of life, then all epistemological binaries and ideas can be mediated. Even our concept of God for Hegel is a dialectical offspring of cultural deliberations. In other words, the nature of reality is fathomable through a series of struggles (both affirmative and negative) since in the first place, nature and reality are rational.

Speaking of God, Hegel relatively assumes that philosophy is also about the Absolute. Contrary to the customary reading of this concept, he conceives it not as an end, but simply as a by-product of concrete struggles. According to him, "Absolute ... is essentially a result ... it is first at the end of what it truly is; and ... precisely in this consists its nature, viz. to be actual,

${ }^{4}$ Hegel, Science of Logic, 31; Cf. Houlgate, The Hegel Reader, 140.

(c) 2014 Raniel SM. Reyes

http://www.kritike.org/journal/issue 15/reyes december2014.pdf

ISSN 1908-7330 
subject, the becoming of itself." 5 It is thus safe to say that the Absolute, being a product of dialectical processes, always has a dimension of becoming-other in nature and history. What is absolute in it is not that all is one, as the formalistic sciences argue; rather, it is the negative movement of the dialectic - the synthesis of difference that is itself differential.

For Hegel, the true Absolute cannot be simply equated with the God of the theologians or Soren Kierkegaard's. Rather, it is the absolute mind formed by the collectivity of the human condition understanding itself $-\mathrm{a}$ totality of truth manifested dialectically in history and not in God's divine consciousness. ${ }^{6}$ In fact, religion (where God is given a deific status) in Hegel's philosophy occupies only a step before philosophy in the achievement of the Absolute. From the antagonism of subjective and objective spirit, they are henceforth differentially reconciled in the absolute. Hereafter, dialectical consciousness finds its expression in the minds of individuals, family, civil society, state, and finally art, religion, and philosophy. It is then very evident that he perceives society to be in a dialectical movement.

Furthermore, Hegel's dialectic carries with it the capability of elevating itself towards self-understanding through a series of contradictions ingrained in the different social institutions. Amidst these series struggles (Aufhebung), the mind realizes itself via the dialectical process. In Hegel's words, "Dialectical movement of negative thinking fuels the spirit. Consequently, a new world is born perpetually, but that which is without any period of full actuality especially in its beginnings. But the actuality of this simple whole consists in those various shapes and forms which have become its moments, and which will now develop and take shape afresh, this time in their new element, in their newly acquired meaning. ${ }^{7}$ Hence, selfunderstanding embedded in the dialectic is a tortuously tedious mission because Absolute knowledge is not even the end; rather, it is the collective consciousness of the society.

The dialectic is not only a concrete description of the internal logic of reality; it is also a praxis. The dialectic enables an immanent examination of the dynamics of social consciousness as opposed to the modern Cartesian and Kantian epistemological traditions, while sustaining its negative fervor: "Dialectic as a negative movement, just as it immediately is, at first appears to consciousness as something which has it at its mercy, and which does not

${ }^{5}$ G.W.F. Hegel, Phenomenology of the Spirit, trans. by A.V. Miller (Oxford: Oxford University Press, 1977), 9. The absolute in Hegel's work can also mean the moments of consciousness or spirit wherein an idea is perceived as a 'totality' of the real.

${ }^{6}$ Cf. G.W.F., Elements of the Philosophy of Right, trans. by Hugh Barr Nisbet, ed. by Allen W. Wood (Cambridge: University of Cambridge Press, 1991), 23.

${ }^{7}$ Houlgate, The Hegel Reader, 50.

(c) 2014 Raniel SM. Reyes

http://www.kritike.org/journal/issue 15/reyes december2014.pdf

ISSN 1908-7330

(cc) BY-NC 
have its source in consciousness itself." 8 It is therefore convincing then to claim that Hegel's own brand of materialist philosophy is a coming-close to society's flaws writ large. For him, the truth is the whole, but the whole is nothing without the parts. The whole is the process of development wherein the parts come to constitute the whole, thereby conditioning its increased depth and complexity. In this manner, the whole's existence is provisional since it is merely a moment in consciousness, which is always open to the process of negation. This process, of course, is an offshoot of the intrinsically contradicting structures of the society itself. As such, it can be claimed that truth can be its own self-movement, rather than a mode of cognition remaining external to its material. ${ }^{9}$

Albeit the genius of Hegel's philosophy levelheadedly personifies the Owl of Minerva of his time, it would still be very difficult for us not to indulge substantial attention to his argument regarding the claim that contradictions (becoming and difference) in history must be understood as toward a unitive movement of the Asbolute Spirit. Being a child of the Enlightenment, this viewpoint is concomitantly informed by an overarching premise that society must become rational, i.e., it must engender the reconciliation of the subjective and the objective spirit via the institutions of the ethical life. This is only achievable in modernity in general and the Prussian state in particular. This is his version of the Archimedian eureka where reality is united with the Notion. However, it must be accentuated that this totalitarian spectrum found in the Hegelian system is the very reason why the critical theorists (especially those from the first generation spearheaded by Theodor Adorno and Max Horkheimer) attempted to salvage this obscure aspect in Hegel's philosophy, using the philosophies of immanent critique and negative dialectics, together with the overriding project of social transformation. Nevertheless, in the continental canon, these social theorists are not alone in this antifoundationalist advocacy, since the Owl of Minerva's arrival into the French soil also has produced fabulous amount of scholarship that deserves considerable attention.

\section{Deleuze's Revaluation of Hegel towards Non-Conceptual Difference}

\section{Deleuze-in-the-making and the Hegelian Achilles Heel}

The most eminent reception of the Hegelian philosophy in the contemporary period comes from the French grain. Although its readership

\footnotetext{
${ }^{8}$ Ibid., 102.

${ }^{9}$ Hegel, Phenomenology of the Spirit, 28.
} 
is still selective, the French's radical prognosis of the dialectics presents us a new treatment in looking at difference, which is irreducible to any assimilative significations. Proponents of this brand of theorization are popularly acknowledged as the philosophers of difference in the likes of Michel Foucault, Jean Franscois Lyotard, Jacques Derrida, and Gilles Deleuze.

From 1940 until 1950, the resonance of the Hegelian voice has penetrated into the French ears, and to their pre-existing theoretical discourses that further strengthened the said system. Now let us explain Deleuze's take on the Hegelian philosophy's arrival to his land, backdropped by the poststructuralist general critique of representationalist thinking for assimilating difference in the regime of metaphysics.

The aftermath of World War II and France's Liberation had a paramount effect on the thoughts of Foucault, Lyotard, Derrida, Deleuze, etc. The 1960s marks a point in France's history when the socio-political atmosphere of the time was greatly opportune in providing the concrete condition for the cultivation of the ideas of young philosophers. ${ }^{10}$ These men became famous in relating their critique of metaphysics, science, and history to the socio-political climate that brought forth philosophical currents, such as postmodernism and poststructuralism. ${ }^{11}$ Deleuze belongs to this intellectual and socio-political milieu.

Deleuze criticizes Hegelian philosophy in a circumvented fashion so as not to simply be a weak prey to it. To be specific, he uses Nietzsche, another German thinker who was re-interpreted by French scholarship in the 1960s. The appropriation of the Nietzschean philosophy is due to the communal frustration with the dominant philosophies at that time, generally influenced by Hegelianism like Marxism and Phenomenology. ${ }^{12}$ Even the different social spaces were already longing for a condition other than what the Hegelian notion of unity, teleology, and the Absolute can offer. This is a possibility that Deleuze finds realizable in the Nietzschean philosophical corpus.

The Nietzsche-Hegel engagement is illustrated by Deleuze primarily in one of his early literatures, Nietzsche and Philosophy. ${ }^{13}$ This book chronicles the exciting battle between these two thinkers in the arena of contemporary

10 See Paul Patton and John Protevi eds., Between Deleuze and Derrida (London: Continuun, 2003).

${ }^{11}$ Jean Francois Lyotard defines postmodernism's primary attitude as the incredulity towards meta-narratives. See Jean-Francois Lyotard, The Postmodern Condition: A Report on Knowledge, trans. by Geoff Bennington and Brian Massumi (Minneapolis: University of Minnesota Press, 1984).

${ }^{12}$ Cf. Robert Sinnerbrink, Understanding Hegelianism (Acumen: Acumen Publishing, 2007), 173. Much of my explication of Deleuze's revaluation of Hegelian philosophy is derived from Sinnerbrink's aforementioned book; and for this, I am greatly thankful.

13 Gilles Deleuze, Nietzsche and Philosophy, trans. by Hugh Tomlinson (New York: Columbia University Press, 1983).

(c) 2014 Raniel SM. Reyes

http://www.kritike.org/journal/issue 15/reyes december2014.pdf

ISSN 1908-7330

(cc) BY-NC 
French philosophy. When the 1968 student protest agitated the French sensibility, this opus assumed a somewhat Biblical status to a wide-range of scholars and the fuming crowd, as this year became an ecstatic moment for everyone to philosophize by violating the monotony of order using not only words but also force.

It is interesting to note that the maxim "God is dead" was conceptualized by Hegel prior to Nietzsche. At first, it was unthinkable that this adage Nietzsche niftily borrowed from Hegel would be the very point of departure of the former to attack the tradition where the latter belongs. According to Nietzsche, since all values depreciate by themselves in the modern epoch, the nihilism corrupting Hegel's historico-cultural dwelling must be revaluated. ${ }^{14}$ Being a part of the whole, Hegel's philosophy is of no exemption to this grand critique of European decay. From Platonism and Christianity's promise of the otherworld, repugnance of the immanent, and the positivistic optimism of science, Deleuze also includes the notion of dialectical history (dialectics) to be one of the most compelling sources of nihilism. In Nietzsche and Philosophy, Deleuze opines that:

History thus appears as the act by which reactive forces take possession of culture or divert its course in their favor. The triumph of reactive forces is not an accident in history but the principle and meaning of "universal history." This idea of a historical degeneration of culture occupies a prominent place in Nietzsche's work: it is an argument in Nietzsche's struggle against the philosophy of history and the dialectics. ${ }^{15}$

In fact, after deliberating the manifold depictions of nihilism across religions, disciplines, and civilizations, Deleuze even dedicates a part in the said book with a title, 'Against Hegelianism.' From the denigration against Hegel's analysis of the death of God proposition as constitutive of degeneration, Deleuze proceeds with a barefaced appraisal of the dialectic principle. Even though Hegel fought the prevalent metaphysics of representation during his time, his dialectic still transforms into another representationalist philosophy. In this manner, it becomes debilitated to go beyond its own symptoms and nemesis because it is already despoiled by the forces of ressentiment and bad conscience. Deleuze further argues that:

${ }^{14}$ Cf. G.W.F., Elements of the Philosophy of Right, 23.

${ }^{15}$ Deleuze, Nietzsche and Philosophy, 139. 
Dialectic thrives on oppositions because it is unaware of far more subtle and subterranean differential mechanisms: topological displacements, typological variations. ... Deprived of all its ambitions, opposition ceases to be formative, impelling and coordinating: it becomes a symptom to be interpreted. Deprived of its claim to give an account of difference, contradiction appears for what it is: a perpetual misinterpretation of difference itself, a confused inversion of genealogy. In fact, to the eye of the genealogist, the labor of the negative is only a coarse approximation to the games of the will to power. ${ }^{16}$

Whereas the Hegelian dialectic always leaves one foot behind in its struggle, Nietzsche's radical philosophy proposes for a total destruction of the past edifice. Although his genealogical critique looks at the past origin of values, it is equipped with a bold quest to qualitatively identify whether they are of slavish or noble origins, and more importantly, to reach the primary protean receptacle of all of these-the Will to Power. ${ }^{17}$

Essentially, the will to power is the differential character of forces. Deleuze explains that life forces and values are only secondary to the will to power. This principle consists of a confluence of forces that still necessitate further engagement with other forces. According to him, "The will to power is the element from which derive both the quantitative difference of related forces and the quality that devolves into each force in this relation. The will to power here reveals its nature as the principle of the synthesis of forces."18 Further, Deleuze conceives that the dialectic is simply operating based on a seemingly superficial normativity, for it only appears as simulating state of the will to power. Even after the demise of God, as well as the reconciliation of God and man, they still retain their identities as epitomes of reactive forces. The Hegelian dream of thought's lofty elevation is thereby undermined. Since this so-called dialectical development of thought only ends as a form of will to nothingness, Deleuze via Nietzsche thinks that it miserably becomes like Christianity - so effective in imposing moral guilt to the crowd, yet deficient in creating new values and possibilities. In other words, although the dialectic has a teleological slate of advancement, it falls short in becoming revolutionary. It is because as things are negated, some values are still preserved in the camel's back (to use a Nietzschean vocabulary), and as such, can still condition the subtle mutation of decadent forces. This mentality of

\footnotetext{
${ }^{16}$ Sinnerbrink, Understanding Hegelianism, 157-158.

${ }^{17}$ Cf. Deleuze, Nietzsche and Philosophy, 52.

${ }^{18} \mathrm{Ibid}$.
}

(c) 2014 Raniel SM. Reyes

http://www.kritike.org/journal/issue 15/reyes december2014.pdf

ISSN 1908-7330

(cc) $\mathrm{BY}-\mathrm{NC}$ 
negation and self-preservation for Nietzsche is constitutive of the last man or the individual who does not have enough audacity to lion all values in pursuit of totally new relations of forces be it biological, economic, or political. Therefore, as modernity engenders God's death, it degenerately crafted some substitute metaphysical guarantors like "permanence," "soul," "Geist," etc., thereby authoring new forms of foundationalism and strengthening nihilism's pervasiveness.

A case in point can be gleaned from Philippine politics. The Filipinos' earnest desire to dethrone their President Joseph Estrada in 2001 has ambiguously positioned Gloria Macapagal-Arroyo (the Vice-President) in the presidential seat. They failed to realize that Arroyo has only romanticized the hype of the people's ire to ploy her malevolent and narcissistic goals for the Philippine society. On a critical perspective, the Filipinos' magnanimous goal of ousting (negation) a corrupt leader engendered them a sightless instillation of another one (preservation). It is a resurrection of tyranny or a recurrence of the Same (despotism) inside a new physiological container (Arroyo's body). ${ }^{19}$

Nietzsche suggests that in order to overcome modern nihilism, we must live dangerously. We must revaluate all existing values whose origins are derived from debased or reactive configurations. After completely obliterating all artifacts of dogmatism and ressentiment, man is now confronted with the task of fashioning new values under the backdrop of life as a will to power. Consequently, with the demise of all metaphysical guarantors such as God, Reason, and Science, life is de-deified and is given a chance to live anew vigorously. This is a day of celebration where other pathways of thriving and spheres of immanence or becoming-closer to the earth are opened to our horizons. It is an existence way beyond the mechanical life of Franz in Milan Kundera's novel Unbearable Lightness of Being, ${ }^{20}$ or that of Roquentin in Jean-Paul Sartre's Nausea. ${ }^{21}$

${ }^{19}$ Cf. Epifanio San Juan, Only By Struggle: Reflections on Philippine Culture, Politics, and Society (Quezon City: Giraffe Books, 2002). A more contemporary instance of this spiteful loop is the so-called debased political recycling which happened last December of 2013 in the aftermath of super typhoon Yolanda (Haiyan). At the commencement of the enduring rehabilitation program by the Philippine government, President Benigno Aquino Jr. designated former senator Panfilo Lacson as the chief officer of the said program. Prior to Lacson's stint, he was deemed fugitive by the previous Arroyo administration. But now he is given another chance to rub out the places wrecked by the typhoon. For Deleuze, this vicious circle is the upshot upon difference's marginalization in the unfolding of history. For the Filipinos, on the other hand, it is the outcome of our despoiled understanding of history, politics, and responsibility, etc.

${ }^{20}$ Milan Kundera, The Unbearable Lightness of Being (New York: Harper and Row Publishing, Inc., 1985).

${ }_{21}$ Jean-Paul Sartre, Nausea, trans. by Robert Baldick (New York: Penguin, Harmondsworth, 1966).

(c) 2014 Raniel SM. Reyes

http://www.kritike.org/journal/issue 15/reyes december2014.pdf

ISSN 1908-7330 
The post-metaphysical culture created amidst nihilism's twilight is an ontology of immanence vitally informed by the Spinozist tradition. ${ }^{22}$ In this regard, Nietzsche affirmatively formulates the typologies of the ascending and the descending ${ }^{23}$ mode of life, and introduces the metaphor of the Eternal Return so as to test us on what kind of life we want to recur. Since values are already based on how we view life and expend our potentialities, their significance depends on whether we are going to recognize it as ascending (noble) or descending (slavish). In other words, the manner on how we value life is identified by the sense of power that we affirmatively cultivate, and not by its truthfulness or falsity. After this transvaluative recommendation, Deleuze further explains that, "Against Hegelian dialectics, which overcomes alienation via the comprehension of our historical experience, Nietzschean genealogy overcomes nihilism by harnessing the active forces of the body and unconscious in order to invent new concepts and modes of existence." 24

\section{From Nietzschean Anti-Dialectics to a Reformulated Hegelianism}

Robert Sinnerbrink is correct to claim that the youthful radical spirit in Deleuze has moderated throughout the production of the Difference and Repetition ${ }^{25}$ at the height of the French revolution. Of course, this ethicoepistemological shift occurring in the career of thinkers is not an exclusive event in philosophy. In the territories of politics, historiography, sociology, and even in ordinary human affairs, it is also observable how individuals at some point of their endeavors realize the viability of past anomalies theoretical or otherwise, and discovered another eureka moment in their vocations. It should not surprise us when heroes become tyrants, extremists become conservatives, and friends become foes, vice versa. I cannot help but parallel this intellectual metamorphosis with Nietzsche's literary career depicted when Zarathustra's goal of informing the modern community

${ }^{22}$ Baruch Spinoza is referred to by Deleuze as the prince of philosophers, especially with his claim that God is Nature (Deus sive Natura). See Gilles Deleuze, Spinoza: Expressionism in Philosophy, trans. by Martin Joughin (New York: Zone Books, 1990), 11.

${ }^{23}$ In the Twilight of the Idols, Nietzsche distinguishes the ascending from the descending life-typology. In his words, "Every individual may be scrutinized to see whether he represents the ascending or the descending line of life. If he represents the ascending line, then his worth is indeed extraordinary and for the sake of life as a whole, which takes the step farther through him, the care for his preservation and for the creation of the best conditions for him may even be extreme ... If he represents the descending development, decay chronic degeneration, and sickness, then he has small worth and the minimum of decay requires that he take away as little as possible from those who have turned out well. He is merely a parasite." Friedrich Nietzsche, Twilight of the Idols, trans. by R.J. Hollingdale (Harmondsworth: Penguin Books, 1968, 33).

${ }^{24}$ Sinnerbrink, Understanding Hegelianism, 177.

${ }^{25}$ Cf. Ibid., 174.

(c) 2014 Raniel SM. Reyes

http://www.kritike.org/journal/issue 15/reyes december2014.pdf

ISSN 1908-7330

(cc) $\mathrm{BY}-\mathrm{NC}$ 
regarding the wisdom of the Overman has toned down towards the end in simply looking for few kindred spirits because of cumbersome disenchantment.

I suppose that this brand of metamorphosis does not only form part of Deleuze's maturity process conditioned by the historical evolution of his time, but also something of a consciously profound self-criticism to his brazen confrontation of the Hegelian dialectic. Meaning to say, in obliquely antagonizing the dialectic via Nietzsche's philosophy, Deleuze is in turn challenged by some structural quandaries derivable from the very system he aspires to push into limits. As such, his project converts into a painstaking reconstruction of the dialectic to develop into a principle receptive to difference, and not to nihilism and representation.

From the dialectics' nihilistic domain, Deleuze's attention progresses into the totalitarian aspect of the Hegelian teleology, equipped with the positive desire to salvage Hegel's endeavor from falling into another metaphysics of domination. His overhauling project is patently informed by his critical diagnosis of the system, which is guilty for marginalizing singularity and sensibility. For if this activity continues, the differential forces and affects of these concepts will not be given evenhanded considerations; they will only be counted as forms of contradictions necessary to achieve another kind of elevated unity.

In the latter part of Deleuze's philosophical career, you can seldom see the name Nietzsche. It only implies that the radically affirmative substance of the Nietzschean philosophy has already been planted in the entire capillaries of the Deleuzian machinery, thereby becoming a rather intuitive blueprint across Deleuze's project. In fact, the Nietzschean philosophy of difference was presented extensively in Difference and Repetition, as a reversal of the Platonic project of representaionalist thinking. Deleuze likewise finds in difference the notion of the non-conceptual that undermines Western rationality's foundationalism like Derrida. ${ }^{26}$ Using this yardstick, the renewed object of philosophy is no longer the ill-fated notion of being or unity, but the intrepid affirmation of difference as the chaotic multiplicity of the world's becoming. ${ }^{27}$ This overturning of Platonism project,

${ }^{26}$ Deleuze and Derrida's contribution to the French Postwar scholarship can be gleaned from their efforts to revive Nietzsche's philosophy of difference. Their philosophies seek to invert Plato's metaphysics and revaluate the Hegelian dialectical philosophy due to their nihilistic and teleological orientations. See Gilles Deleuze, Negotiations, trans. by Martin Joughin (New York: Columbia University Press, 1995), 88; Patton and Protevi, Between Deleuze and Derrida, 4.

${ }^{27}$ Ronal Bogue, Deleuze and Guattari (New York: Routledge, 1989), 32.

(c) 2014 Raniel SM. Reyes

http://www.kritike.org/journal/issue 15/reyes december2014.pdf

ISSN 1908-7330 
therefore, has morphed into a fluid philosophy that replaces Hegel's negation of negation with a Heraclitean philosophy of affirmation. ${ }^{28}$

Deleuze's shift from an overall appraisal to a mere reconstruction of the Hegelian dialectic offers an invitation for a new genealogy, principally in relation to his stellar friendship with his mentor Jean Hyppolite. His teacher's kaleidoscopic reading of Hegel launches an antagonism to the predominant philosophy of being or dialectical unity of reason that substantially complemented his philosophy of difference's war-cry. As Hyppolite resorted to Martin Heidegger's philosophy in his mature years, his project was accused by Deleuze of still dwindling into the Hegelian notion of conceptual difference where difference itself is recognized merely as a form of contradiction. On the other hand, Nietzsche, in his later career, parted way with Wagner because of his mathematized aesthetics, that is, "for retaining too much harmonic form, and too many pedagogical personages: too much Hegel." 29 In Deleuze's case, this signals the time of his critical distantiation from his mentor. In opposition to Hyppolite, he suggests the reformulation of the concept of difference that is pure in-itself and is irreducible to the categorization of contradiction and identity. Difference in-itself for him is "something which distinguishes itself from other things, imagine something which distinguishes itself, and yet in distinguishing itself it does not distinguish itself from the other." 30 Hence, it is only in the fluid state of pure difference where non-conceptual difference is possible.

In addition, difference in-itself is a thinking of pure difference unfounded on the principle of identity. In the language of Deleuze, "We propose to think difference in-itself independently of the forms of representation which reduce it to the Same, and the relation of different to different independently of those forms which make it pass through the negative." 31 This aforementioned concept of the later Deleuze develops into the principle of nomadic thought. Contrary to the striated interiority circulating within the veins of representationalism, this revitalized concept mobilizes freely in an element of exteriority, as it rides in the smooth and open-ended plateau of difference. ${ }^{32}$

${ }^{28}$ In the Twilight of the Idols, Nietzsche explains his appreciation to the ancient philosopher Heraclitus: "With the highest respect, I except the name of Heraclitus. When the rest of the philosophic folk rejected the testimony of the senses because they showed multiplicity and change, he rejected their testimony because they showed things as if they had permanence and unity." Nietzsche, Twilight of the Idols, 2.

${ }^{29}$ Gilles Deleuze, and Felix Guattari, A Thousand Plateaus: Capitalism and Schizophrenia, trans. by Brian Massumi (London: The Athlone Press, 1988), 269.

${ }^{30}$ Gilles Deleuze, Difference and Repetition, trans. by Paul Patton (New York: Columbia University Press, 1994), 43.

${ }^{31}$ Ibid., xix.

${ }^{32}$ Deleuze and Guattari, A Thousand Plateaus, xii.

(C) 2014 Raniel SM. Reyes

http://www.kritike.org/journal/issue 15/reyes december2014.pdf

ISSN 1908-7330

(cc) BY-NC 
Based on the above-explanation, Deleuze's radical philosophy can be portrayed as an immanent critique and reconstruction of the Hegelian dialectic. Like the critical theorists who remain ambivalently Hegelians after salvaging Hegel from its teleological pathology, he penetrates this dialectical tradition like a new Socrates who would remind his fellowmen about the virtualities of non-conceptual difference. As a radical thinker, Deleuze strives to pursue the possibility of conceiving the dialectic without a teleological unity waiting at the end of the road. He is no Marx or Lenin in this aspect. But he is a philosopher whose unwavering thrust is the differential dialectic of the play of multiple becomings in the world of the chaosmos. ${ }^{33}$ To roughly explicate this point, let me quote a poem by Antonio Mechado entitled, There Is No Road: "Traveler, your footprints are the only road, and nothing more ... there is no road, the road is made by walking." 34 This rhizomic voyage is comparable to teaching and sacrificing your entire youth in the university just to inspire students to go beyond the rabbit's fur or imagine higher causes, without knowing exactly what road or direction your feet will lead you to. But along the way, you will realize that you have fashioned roads of possibilities because of your nomadic efforts.

Deleuze's major challenge then is to perceive the dialectics in terms of problematics, rather than of propositions and reconciliations, as well as to invert the subordination of difference to identity, negativity, and contradiction, towards thought's liberation from the yoke of representationalist thinking. ${ }^{35} \mathrm{He}$ extends his project to history's landscape since the dialectics is the blood-line of historical unfoldings. Historical progression, for him, does not happen due to dialectical movement of the negation of negation, but rather, due to the affirmation of difference and problem-decisions. ${ }^{36}$ This is so because contradictions in reality can anytime be manipulated by those in power (politicians, capitalists, or psychoanalysts), be it for the maintenance of the status quo or for the justification of exploitation. From a wider perspective, philosophical thinking must learn the logic of the dice-throw amidst the experience of chaos since this is the very state that it would be awakened from its slavish and essentialist slumber. This is the ardent time for philosophy's chaoticizing of itself in front of difference. When Deleuze contends that thought must confront chaos, it is not in order to vanquish chaos for that would condition once again the possibility of

33 "Chaosmos" is a term which means the dynamic harmony between chaos and cosmos. It is the affirmation of chance and necessity. Albeit for Nietzsche (in the eyes of Deleuze) the universe is of chaotic character, it is not in contradiction to necessity.

${ }^{34}$ Mechado Antonio, From Selected Poems of Antonio Mechado, trans. by Betty Craige (University of Georgia: LSU Press, 1978), 76.

${ }^{35}$ Cf. Sinnerbrink, Understanding Hegelianism, 183.

${ }^{36}$ Cf. Deleuze, Difference and Repetition, 268. 
reverting to representationalism. Rather, it is to delineate a plane of consistency comprising of heterogeneous forces. These forces are constitutive of chaos acting as a bastion of creativity, active forces and infinite possibilities. Meaning to say, instead of waiting for the Owl of Minerva to arrive, a time where all things will synthesize towards higher forms of unity, let us indefatigably disturb the present totalized representationalism through the invention of new concepts and lines of flight. This is what Deleuze calls as differential thinking or non-conceptual difference.

If Deleuze' diagnosis of Hegel's notion of becoming is explicitly depicted in Difference and Repetition, his undermining of Hegel's notion of universal history and its predominant teleological spirit are profoundly elaborated in the later writings, especially in Anti-Oedipus and $A$ Thousand Plateaus. ${ }^{37}$ At first glance, becoming a philosopher of difference while simultaneously being equipped with a notion of a universal history would bring Deleuze into an unfavorable situation. However, this philosophical quandary is only feasible when we limit our understanding to the concept of universal history by virtue of modern representationalism or Hegelian foundationalism.

Deleuze's universal history circumvents Hegel's via a turn to Marx's relation to capitalism. The reason is that Marx's historical materialism radiates on "its contingent, singular existence, its irony, and its own critique." 38 In this vein, what is illustrated is a universal history ironically epitomized by capitalism due to its ingrained capability of fashioning both its own nemesis, and of transfiguring the society into a self-critical assemblage. This rather paradoxical kind of history authored by capitalism's immanent and ever-elastic logic was observed by Deleuze to subsist also, even in the field of psychoanalysis in relation to the Oedipal universality of desire. ${ }^{39}$ Subsequently, Deleuze chaoticizes Marx's corpus through a reformulated concept of individual production already outside the realm of economic activity, or the labor's subordination to capital. Production is deterritorialized to fabulate difference that is capable of surmounting any striated spaces. Nevertheless, capitalism can only afford us a potentiality or the precondition for a universal history, and not its actual foundations because it "has not always existed; history as a world history is a result." 40 It is only when the Deleuzian philosophy of difference emancipates capital from the economic

\footnotetext{
${ }^{37}$ Gilles Deleuze, and Felix Guattari, Anti-Oedipus: Capitalism and Schizophrenia, trans. by Robert Hurley, Mark Seem, and Helen R. Lane (Minneapolis: University of Minnesota Press, 1983); Deleuze and Guattari, A Thousand Plateaus.

38 Deleuze and Guattari, A Thousand Plateaus, 271.

${ }^{39}$ Eugene Holland, Deleuze and Guattari's Anti-Oedipus: Introduction to Schizoanalysis (New York: Routledge Inc., 1999).

${ }^{40}$ Karl, Marx, Grundrisse: Introduction to the Critique of Political Economy (New York: Vintage, 1973), 11.

(c) 2014 Raniel SM. Reyes

http://www.kritike.org/journal/issue 15/reyes december2014.pdf

ISSN 1908-7330

(cc) $\mathrm{BY}-\mathrm{NC}$
} 
constraints of the market that the proliferation of difference can be engendered and freedom in universal history become immanent. ${ }^{41}$

Hegel's dialectical history obliterates the occurrences of differential events in the material field of life and appropriates the subject into necessary principles and logical structures under the backdrop of the Absolute's regulative potency. Since the individual merely metamorphoses into a cog inside the Hegelian machine of universal history (that devours the possibility of fabulations), Deleuze deterritorializes the structurality of this totalizing principle to arrive at a reformulated notion of a universal history grounded on multiplicity. This Deleuzian notion of history undermines the underlying Hegelian-Marxist belief that history is a form of an organism that is capable of fashioning its own self-destruction and healing. In furthering this, he deterritorializes the codifications of history-as-organism towards the formulation of a history constitutive of nomadic movement and becomings. This dynamic type of becoming-history, for Deleuze and Guattari, is a:

Multiplicity that never allows itself to be overcoded ... All multiplicities are flat, in the sense that they fill or occupy all of their dimensions: plane of consistency of multiplicities, even though the dimensions of this 'plane' increase with the number of connections that are made on it. Multiplicities are defined by the outside: by the abstract line, the line of flight or deterritorialization according to which they change in nature and connect with other multiplicities. ${ }^{42}$

This aforementioned juvenile principle opens its horizon to the aesthetic possibilities and virtualities of life. Under this revitalized concept, history (philosophical history) gains a power to be incessantly critical of itself without necessarily being totalized by the principle of the Absolute. ${ }^{43}$ This novel project radiates an intrinsic vitality of ceaseless ingenuity that is hospitable to the dynamics of becoming and difference. Hence, it renders history its reconfigured universality. This Deleuzian historicizing involves rhizomic materialities which can stimulate the construction of new radical

${ }^{41}$ Cf. Eugene Holland, Deleuze and Guattari's Anti-Oedipus: Introduction to Schizoanalysis (New York: Routledge Inc, 1999); Adrian Parr ed., The Deleuze Dictionary (Manchester: Edinburg University Press, 2005).

${ }^{42}$ Deleuze and Guattari, A Thousand Plateaus, 30.

${ }^{43}$ Craig Lundy, Craig, History and Becoming (Edinburg: Edinburg University Press, 2013); Daniel Smith and Henry Somers-Hall, The Cambridge Companion to Deleuze (Cambridge: Cambridge University Press, 2012).

(C) 2014 Raniel SM. Reyes

http://www.kritike.org/journal/issue 15/reyes december2014.pdf

ISSN 1908-7330 
machines, untimely concepts, and variegated lines of flight, in pursuit of a world and people-to-come. ${ }^{44}$

\section{Differential Harmony and Philosophy, Once Again}

The genius of the Hegelian dialectic stands steadfast on the claim that any kind of opposition can simply be absorbed by this principle as a register of contradiction towards a higher form of unity. We should not be forgetful that Soren Kierkegaard's philosophies of indirect communication and subjective truth, as rigorous resistances contra the Hegelian tradition of his time, simply ended being overshadowed by Hegelianism. ${ }^{45}$ In my case, I did not even imagine that my initial goal of comprehensively antagonizing the Hegelian system through Deleuze would mollify my exorbitant vigor and would let me appreciate the said philosophy more. This extenuation becomes possible via an affirmative Deleuze-ing of Hegel, which is likewise a Deleuzeing of Deleuze himself. Accordingly, it makes me realize and re-think some of the concealed penchants and lapses of Deleuze, and it leads me to recognize that he is only human, conditioned by the material contingencies of his time and by the ink of his pen.

Deleuze's interpretation of Nietzsche is so lucid that he already turns heedless to Hegel's sterling scholarship. Contemporary authors like Stephen Houlgate and Catherine Mallarme have plausibly observed this prejudice. In fact, Deleuze's famous invitation of becoming non-philosophical as a necessary qualification for renewed philosophical thinking is already addressed in Hegel's lectures on the Absolute spirit, Art, and Religion. The latter's re-definition of philosophy from being a theoretical discourse to a creative attitude proposes its inclusivity to other disciplines. In this discursive democratization, every voice is given a chance to say something about the particular and the whole and is occasioned for perpetual examination. This is the reason why Deleuze even proceeds to literature and science-fiction movies in his ingenious imagination of a people and world-to-come. And it is only when each voice realizes an urge for self-reflection and critique, especially in relation to decadent institutions and despotic machines, that it can be sublated towards higher forms of unity, which in the contemporary scheme of things, must be conceived in the light of constellations and social

${ }^{44}$ Gilles Deleuze and Felix Guattari, What is Philosophy?, trans. by Hugh Tomlinson and Graham Burchell (New York: Columbia University Press, 1994); Gilles Deleuze and Claire Parnet, Dialogues, trans. by Hugh Tomlinson and Barbara Habberjmn (London: Continuum, 2002).

${ }^{45}$ Soren Kierkegaard, Fear and Trembling (London: Penguin Books, 1985).

(c) 2014 Raniel SM. Reyes

http://www.kritike.org/journal/issue 15/reyes december2014.pdf

ISSN 1908-7330

(cc) $\mathrm{BY}-\mathrm{NC}$ 
transformation. But just a caveat, this coarse armistice between their philosophies is not as simple as it may appear.

In the Philippines, Hegelian philosophy adherents would say (akin to the Estrada-Arroyo instance earlier-cited) that from hindsight, Arroyo's delusion of political supremacy was justified for it ignited the fire within the Filipinos' heart, enough for the entire nation to condemn her whole-sale. This malady, among other social contagions adulterating our society, has noticeably elevated the people's critical consciousness and has generated praxiological desiring-machines for their conscientization on the significance of nation-building, social activism, ethical responsibility, etc. It has also raised many questions as to what kind of public governance and historical dialectics the Filipino people want in the future.

At this moment, it is interesting to reflect on these queries: What is in the Philippines' EDSA II revolution that produced the autocrat Gloria Macapagal-Arroyo rather than a noble leader? What is in Thailand that empowered its people to nullify its democratic government just for the debased Thaksin-influenced regime not to surface its renaissance? What is in the dehumanizing Apartheid in South Africa that yielded and eulogized the great man Nelson Mandela, in the same strain that India produced Mahatma Gandhi? Certainly, there are times that instead of slavishly readying ourselves from the rationality given to us by the Hegelian 'hindsight analysis' (capacitated of providing us both destruction and development), we must be ruthlessly critical regarding our perennial pursuit for a collective identity as a groundwork for an anti-tyrannical and anti-foundational machinery. It is because it will always be susceptible to the homogenizing ploy organized by the despotic system itself.

The relatively enigmatic relationship between Hegel and Deleuze depicts us an enthralling philosophical relation and problem that have been enticing mounting interest among contemporary scholars. In the article "Nomadology or Ideology," Sinnerbrink posits the two prevailing approaches to this predicament: the assimilationist reading and the radical separatist. ${ }^{46}$ The former upholds that despite his self-confessed antiHegelianism, Deleuze inescapably falls into the rubric of the Hegelian dialectic. This viewpoint, which I alluded a while ago, is discernible in the projects of cultural theorists like Catherine Malabou and Slavoj Zizek. The latter perspective argues the impossibility of compromise between Hegel and Deleuze. This stance is famously represented by Michael Hardt and Brian Massumi. In this regard, Sinnerbrink opines that, "not surprisingly, we could summarize this difference as that between the Hegelian claim that Deleuzian difference does not entirely escape the movement of dialectics, and the more

${ }^{46}$ Robert Sinnerbrink, "Nomadology or Ideology," in Parrhesia, 1 (2006), 62-87.

(c) 2014 Raniel SM. Reyes

http://www.kritike.org/journal/issue 15/reyes december2014.pdf

ISSN 1908-7330 
Nietzschean claim that Deleuze's thought remains irreducible to the movement of dialectical integration of difference into a more complex unity." 47

At the end of the day, in spite of Hegel and Deleuze's rigorous attempts to diagnose representationalism and free philosophy from conceptual reification, they have not successfully emancipated their respective projects in the ubiquitous privileging of philosophy in the history of western tradition, pondered by some as the philosopher's bad faith. In other words, despite Hegel's critical appraisal of modern epistemologies and Deleuze's radical reconstruction of the Platonic and Hegelian philosophy, they still converge to what many call as the privileging of philosophy scheme-always carrying the quicksand of essentialism on its back. Notwithstanding this perennially inexorable conundrum, philosophy can still deterritorialize itself by becoming-nomadic, minortarian, and aesthetic, in order to midwife creativity and difference from the womb of the only ontology we cannot deny-LIFE.

\author{
Department of Philosophy \\ The Graduate School \\ University of Santo Tomas, Philippines
}

\title{
References
}

Beiser, Frederick, ed., The Cambridge Companion to Hegel (Cambridge: Cambridge University Press, 1993).

Bogue, Ronald, Deleuze and Guattari (New York: Routledge, 1989).

Deleuze, Gilles, Nietzsche and Philosophy, trans. by Hugh Tomlinson (New York: Columbia University Press, 1983). Difference and Repetition, trans. by Paul Patton (New York: Columbia University Press, 1994). Negotiations, trans. by Martin Joughin (New York: Columbia University Press, 1995). Spinoza: Expressionism in Philosophy, trans. by Martin Joughin (New York: Zone Books, 1990). The Logic of Sense, trans. by Mark Lester (New York: Columbia University Press, 1990).

Deleuze, Gilles and Guattari, Felix, Anti-Oedipus: Capitalism and Schizophrenia, trans. by Robert Hurley, Mark Seem, and Helen R. Lane (Minneapolis: University of Minnesota Press, 1983).

${ }^{47}$ Ibid., 62

(C) 2014 Raniel SM. Reyes http://www.kritike.org/journal/issue 15/reyes december2014.pdf ISSN 1908-7330 
A Thousand Plateaus: Capitalism and Schizophrenia, trans. by Brian Massumi (London: The Athlone Press, 1988). What is Philosophy?, trans. by Hugh Tomlinson and Graham Burchell (New York: Columbia University Press, 1994).

Deleuze, Gilles and Parnet, Claire, Dialogues, trans. by Hugh Tomlinson and Barbara Habberjmn (London: Continuum, 2002).

Hegel, G.W.F., Elements of the Philosophy of Right, trans. by Hugh Barr Nisbet, ed. Allen W. Wood (Cambridge: University of Cambridge Press, 1991).

Phenomenology of the Spirit, trans. by A.V. Miller (Oxford: Oxford University Press, 1977).

Hegel's Science of Logic, trans. by A. V. Miller (London: Allen \& Unwin New York: Humanities Press, 1969).

Holland, Eugene, Deleuze and Guattari's Anti-Oedipus: Introduction to Schizoanalysis (New York: Routledge Inc., 1999).

Houlgate, Stephen, The Hegel Reader (MA: Blackwell Publishing, 1988).

, The Opening of Hegel's Logic: From Being to Infinity (USA: Purdue University Press, 2006).

Kierkegaard, Soren, Fear and Trembling (London: Penguin Books, 1985).

Kundera, Milan, The Unbearable Lightness of Being (New York: Harper and Row Publishing, Inc., 1985).

Lundy, Craig, History and Becoming (Edinburg: Edinburg University Press, 2012).

Marx, Karl, Grundrisse: Introduction to the Critique of Political Economy (New York: Vintage, 1973).

Mechado, Antonio, From Selected Poems of Antonio Mechado, trans. by Betty Craige (University of Georgia: LSU Press, 1978).

Nietzsche, Friedrich, Beyond Good and Evil: Prelude to a Philosophy of the Future, trans. by Walter Kaufmann (New York: Vintage, 1966).

On the Genealogy of Morals, trans. by Walter Kaufmann, in Basic Writings of Nietzsche (New York: Modern Library, 2000).

Thus Spoke Zarathustra: A Book For Everyone and No One, trans. with an intro. by R.J. Hollingdale (London: Penguin Books, 1969). Twilight of the Idols, trans. by R.J. Hollingdale (Harmondsworth: Penguin Books, 1968).

Parr, Adrian, ed., The Deleuze Dictionary. Manchester (Edinburg University Press, 2005).

Patton, Paul and Protevi, John, Between Deleuze and Derrida (London: Continuun, 2003).

San Juan Epifanio, Only By Struggle: Reflections on Philippine Culture, Politics, and Society (Quezon City: Giraffe Books, 2002).

(C) 2014 Raniel SM. Reyes

http://www.kritike.org/journal/issue 15/reyes december2014.pdf

ISSN 1908-7330 


\section{DELEUZE CONTRA HEGEL}

Sartre, Jean-Paul, Nausea, trans. by Robert Baldick (New York: Penguin, Harmondsworth, 1966).

Smith, Daniel, and Somers-Hall, Henry, The Cambridge Companion to Deleuze (Cambridge: Cambridge University Press, 2012).

Sinnerbrink, Robert, "Nomadology or Ideology" in Parrhesia, 1, 62-87 (2006). Understanding Hegelianism (Acumen: Acumen Publishing, 2007). 